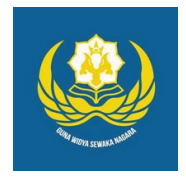

Jurnal Analogi Hukum

Journal Homepage: https://ejournal.warmadewa.ac.id/index.php/analogihukum

\title{
Kebijakan Perlindungan Hukum Terhadap Konsumen Online Market Place Akibat Dampak Covid-19
}

\author{
I Made Amertha Wiguna, I Nyoman Putu Budiartha dan Ida Ayu Putu Widiati \\ Universitas Warmadewa, Denpasar-Bali, Indonesia \\ amerthaw@gmail.com

\begin{abstract}
How To Cite:
Wiguna, I, M, A., Budiartha, I, N, P., Widiati, I, A, P. (2021). Kebijakan Perlindungan Hukum Terhadap Konsumen Online Market Place Akibat Dampak Covid-19. Jurnal Analogi Hukum. 3 (2). 135-141. Doi: https://doi.org/10.22225/ah.3.2.2021.135-141
\end{abstract}

\begin{abstract}
The increasing number of online marketplace users continues to increase which also leads to increased crime, on the other hand the weak legal protection regulations. The formulation of the problem raised is How does the legal protection policy for online marketplace consumers impact Covid-19? What are the legal implications of the spread of covid-19 for online marketplace consumers? This thesis research is carried out using the normative research type. The results show that legal protection for consumers in online marketplace transactions has not been effectively carried out because in the UUPK regulations, the ITE Law, the Trade Law, PP PSTE, and PP PMSE, the contents of the regulations overlap and are inconsistent. Regulations on legal protection policies that are tailored to current and future needs are needed in order to protect consumers and support the operation of online marketplace transactions. Then provide a reference for the government as a material for consideration in order to improve legal protection policy regulations related to online transactions; 1) Fixing legal protection rules, 2) In making rules, it is necessary to involve private parties, 3) The need for good coordination between government institutions, 4) Carry out online consumer dispute resolution effectively using SiPENA.
\end{abstract}

Keywords: crime; E-Commerce; online transactions

Abstrak-Peningkatan pengguna online marketplace terus meningkat juga membuat meningkatnya tindak kejahatan, disisi lain lemahnya peraturan perlindungan hukum. Rumusan masalah yang diangkat yaitu Bagaimanakah kebijakan perlindungan hukum terhadap konsumen online marketplace berdampak covid-

19?, Bagaimanakah implikasi hukum penyebaran covid-19 terhadap konsumen online marketplace? Penelitian skripsi ini dilaksanakan menggunakan tipe penelitian normatif. Hasil penelitian menunjukan pelindungan hukum terhadap konsumen pada transaksi online marketplace belum efektif dilakukan karena didalam peraturan UUPK, UU ITE, UU Perdagangan, PP PSTE, dan PP PMSE, isi peraturannya tumpang tindih serta tidak kosisten perlu diselaraskannya peraturan tersebut. Diperlukam regulasi kebijakan perlindungan hukum yang disesuaikan dengan kebutuhan saat ini dan kedepan, agar dapat melindungi konsumen, menyokong jalannya transaksi online marketplace. Maka memberikan referensi untuk pemerintah sebagai bahan pertimbangan dalam rangka memperbaiki regulasi kebijakan perlindungan hukum terkait transaksi online; 1) Membenahi aturan perlindungan hukum, 2) Dalam membuat aturan perlu melibatkan pihak swasta, 3) Perlunya koordinasi yang baik antar institusi pemerintah, 4) Melakukan penyelesaian sengketa konsumen secara online dengan efektif memakai SiPENA.

Kata kunci: kejahatan; perdagangan elektronik; transaksi daring

\section{Pendahuluan}

Kondisi penyebaran covid-19 sangat berdampak keberbagai aspek kehidupan tidak hanya kesehatan tetapi ekonomi juga berdampak. Pemerintah mengeluarkan berbagai kebijakan guna mengatasi penyebaran virus ini salah satunya, kebijakan bekerja dari rumah masing-masing guna mencegah dan memmotong rantai penyebaran virus. Sehingga membuat masyarakat melakukan berbagai kegiatan dari rumah. Hasilnya masyarakat mau tidak mau mencari solusi dan alternative guna mengatasi permasalahan yang dialami, masyarakat pun banyak melirik menggunakan media online marketplace yang dijadikan solusi guna mengatasi masalah yang terjadi 
ditengah pademi covid-19. Masyarakat pun akhirnya membuka usaha secara online guna menari rejeki untuk memenuhi kebutuhan sehari-hari akibat kehilangan pekerjaan, serta masyarakat juga mencari keperluan sehari-hari melalui media online marketplace karena kemudahan dan kecanggihan fitur yang ditawarkan dalam penggunaannya yang sangat bermanfaat bagi masyarakat. Sehingga disatu sisi membuat pengguna online marketplace meningkat tajam, ini membuat secara tidak langsung online marketplace juga terkena dampak covid-19. Beriringan dengan meningkatnya pengguna tersebut, bersamaan juga membuat meningkatnya tingkat kejahatan dalam transakasi online marketplace yang menyasar masyarkat sebagai konsumen dalam online marketplace dengan berbagai modus tindak kejahatan seperti penipuan yang membuat timbulnya masalah hukum dan sangat mengancam hak-hak masyarakat sebagai konsumen.

Jika melihat peraturan yang mengatur terkait yang mengatur dalam perlindungan hukum pada konsumen dalam transaksi online marketplace masih lemah disebabkan banyaknya kekurang yang dimiliki oelh masing -masing peraturan tersebut, seperti yakni pada UU No. 8 Tahun 1999 baru mengatur hak dan kewajiban konsumen serta tanggung jawab pelaku usaha dalam transaksi yang dilakukan secara konvensional atau tradisional saja sedangkan pelindungan konsumen dalam transaksi menggunakan sistem online belum dapat merujuk pada UUPK. Sedangkan UU ITE memberikan kebebasaan dala transaksi tanpa melihat pantas/cakapnya pelaku usaha dan konsumen dalam melakukannya tidak mengatur dalam ketentuan peraturanya mengenai umut tersebut. Lalu UU Perdagangan dalam perbelakuan pemberian sanksi hanya memberikan sanksi adminitrasi yakni pencabutan ijin usaha saja jadi kurang efektif dalam menangani masalah hukum yang timbul. Aturan terkait tidak bisa mengatasi serta mencapai masalah yang terjadi dalam transaksi online marketplace dikondisi pademi saat ini, peraturan terkait belum memadai maka menyebabkan perlindungan hukumnya menjadi tidak bisa efektif diberika kepada konsumen, jika dilihat belum selaranya UU yang terkait satu sama lain. Diperlukan legalitas hukum dalam mengatasi masalah hukum pada transaksi online marketplace kedepan yakni dengan suatu payung hukum yang mempunyai kepastian hukum yang kuat dalam melindungi hak yang dipunyai masyarakat sebagai konsumen. Terlebih marketplace telah menjadi pilihan serta solusi untuk tempat transaksi online oleh sebagian besar masyarakat ditengah pademi virus covid19 , dengan tentunya

mempunyai konsekuensi adanya kejahatan didalamnya yang lebih sulit ditindak dibandingkan dengan kejahatan pada transaksi dagang konvensional.

Berdasarkan uraian permasalahan yang telah penulis kemukakan diatas, maka dapat ditarik rumusan-rumusan permasalahan pokok diantaranya yaitu:

Bagaimana kebijakan perlindungan hukum terhadap konsumen online Marketplace akibat dampak covid -19 ? Bagaimana implikasi hukum penyebaran covid-19 terhadap konsumen online marketplace?

\section{Metode}

Penelitian mengenai Kebijakan Pelindungan Hukum Terhadap Konsumen Online Marketplace berdampak Covid-19 memakai penelitian hukum normatif berlandaskan pada studi kepustakaan hukum serta melaksanakan pendekatan masalah secara konseptual dari sudut pandang hukum. Serta penelitian ini memakai bahan hukum primer, sekunder, dan tersier. Bahan hukum yang didapatkan yang terkait dengan permasalahan yang diteliti mengenai perlindungan hukum terhadap konsumen online marketplace. Setelah semua bahan hukum terkumpul kemudian dianalisis secara sistematis dengan menggunakan argumentasi hukum yang tepat, agar dapat menjawab permasalahan yang diteliti dengan berdasarkan logika hukum dari deduktif induktif sesuai dari tujuan penelitian.

\section{Hasil dan Pembahasan}

\section{Kebijakan Perlindungan Hukum Terhadap Konsumen Online Marketplace Akibat Dampak Covid-19}

Meningkatnya berbagai upaya kejahatan yang timbul oleh pemanfaatan kecanggihan teknologi informasi dalam transaksi online marketplace yang terjadi akibat dampak covid19 harus dihadapi dengan memerlukan penyesuaian dalam penanganan serta penegakan dan aturan hukum terhadap tindak kejahatan dengan sistem kejahatan yang menfaatkan teknologi. Kurangnya rasa tanggung jawab dari pendiri situs online marketplace membuat praktek-praktek kecurang sering timbul

baik itu menyangkut dengan palaku usaha, 
barang yang dibeli, lalu harga barang tersebut, serta juga dalam hal pembayaran oleh konsumen. Kecurangan yang dilakukan pelaku usaha berbagai macam misalnya barang yang seharusnya dikirim tidak dikirim maupun barang yang dikirim tidak sesuai yang pesan maupun barang tersebut cacat atau rusak dan dalam pembayaran pelaku usaha mengaku belum menerima pembayaran padahal konsumen melaksanakan pembayaran (A. Halim Barkatullah, 2003; 150)

Melihat alasan tersebut ada berberapa alasan yang menyebabkan transaksi online tidak selalu memberikan manfaat pada konsumen; Pertama karena alasan lemahnya regulasi kebijakan perlindungan hukum terhadap konsumen; Kedua pihak pelaku usaha serta pihak online marketplace tidak selalu mempunyai itikad baik dalam bertransaksi; Ketiga perjanjian baku yang dipakai dalam transaksi oleh pihak online marketplace sulit di mengerti oleh kebanyakan konsumen; Kempat belum sepenuhnya peraturan yang ada saat ini menjamin perlindungan data pribadi terhadap konsumen; Kelima dari segi literasi serta pemberdayaan konsumen masih lemah ( Janus Sidabalok, 2014; 91). Meningkatnya statistik kasus dan pengaduan yang tercatat oleh YLKI dan BPKN membuktikan tingkat permasalahan hukum yang terjadi pada konsumen dalam melakukan transaksi online baik itu marketplace atau sejenisnya, dalam situasi pademi covid-19 meningkat dari tahun sebelumnya itu berarti dalam situasi pademi covid-19 ini tindak kejahatan telah menyasar transaksi online terlebih juga meningkatnya pengguna transaksi online.

Mengidentifikasi permasalahan yang terjadi saat konsumen melaksanakan transaksi online marketplace disebabkan karena; Pertama karena pada saat konsumen melaksanakan transaksi tidak bisa mengenali, memeriksa, dan mengetahui wujud barang yang dipesannya; Kedua informasi mengenai produk sering tidak lengkap didapatkan oleh konsumen oleh pihak pelaku usaha; Ketiga mengenai informasi domisili pelaku usaha sulit didapat sehingga sulit dalam melaksanakan gugatan hukum ketika terjadi sengketa; Kempat tidak tersedianya keamanan jaminan dalam transaksi mengenai risiko kemungkinan yang mungkin terjadi pada saat konsumen melaksanakan pembayaran dahulu padahal barang

tersebut baru akan dikirim saat sudah melakukan pembayaran, kemungkinan barang tidak dikirim bisa terjadi; Kelima terjadinya masalah saat transaksi berbeda negara terjadi sengketa yang membuat yurisdiksi hukum negara mana yang digunakan (A. Halim Barkahtullah, 2009: 35). Maka diperlukan kebijakan perlindungan hukum yang relevan terhadap konsumen dalam bertransaksi online marketplace guna menjamin hak-hak yang dipunyai konsumen tidak dirampas oleh pelaku usaha maupun pihak siapapun terlebih dikondisi ekonomi masyarakat Indonesia yang sedang mengalami kesulitan ditengah pademi covid-19. Sebenarnya perlindungan hukum dapat dilaksanakan melalui dua sarana yakni, Pertama melalui perlindungan hukum preventif mempunyai maksud perlindungan hukum yang memberikan pencegah timbulnya sebuah masalah hukum maupun sengketa hukum; Kedua melalui perlindungan hukum represif mempunyai maksud perlindungan hukum yang mempunyai peran sebagai penyelesai atau untuk mengatasi ketika terjadi sebuah masalah hukum mapun sengketa hukum ( I Dewa Gede Atmadja, I Nyoman Putu Budiartha, 2018: 166).

Melakukan perlindungan hukum untuk konsumen sebenarnya dapat dilaksankan dengan melakukan, Pertama membentuk tatanan aturan perlindungan hukum yang mempunyai informasi yang jelas serta mudah diakses dalam terjaminnya kepastian hukum; Kedua terjaminnya terlindungnya hak konsumen khususnya maupun pada pelaku usaha; Ketiga tingkatkan standarisasi barang maupu jasa agar naiknya kualitasnya; Kempat memberikan sanksi tegas agar memberikan rasa takut atau jera sehingga pelaku usaha enggan melakukan penipuan mapun menyesatkan konsumen guna menjauhkan konsumen dari tindak kejahatan; Kelima menyelaraskan serta mengkolaborasi pelaksanaan mapun perkembangan aturan perlindungan hukum pada konsumen melaksanakan melalui perlindungan bidang yang terkait lainnya (Nurmadjito, 2000: 7).

Jika melihat undang-undang mengatur terkait tranksaksi online marketplace sendiri dirasa belum efektif, dan dirasa tumpang tindih serta perlu diselaraskan antar undang-undang satu dengan undang-undang lainnya. Bisa dilakukan dengan membuat regulasi kebijakan yang baru atau merevisi undang- undang yang sudah ada agar mampu menghadapin dan mengatasi permasalah

hukum yang terjadi dalam transaksi eletronik yang terus berkembang tiap saat terlebih disituasi pademi covid-19 meningkatnya pengguna transaksi online ini. Selain itu, regulasi terhadap transaksi belum ketat dampaknya masif serta meresahkan masyarakat sebagai konsumen. Ada beberapa 
faktor penyebab belum efektifnya Aturan UU yang terkait, yakni kelemahan dalam menangani permasalahan yang terjadi dalam transaksi online saat ini, yakni:

Pertama pada UU No 8 Tahun 1999 (UUPK) mempunyai kelemahan saat ini hanya berlaku untuk transaksi dalam yurisdiksi Indonesia, ketentuan pasalnya mengenai hak mengkhusus pada pelaksanaan transaksi online belum memadai seperti perlindungan serta keamanan dalam hal data atau kerahasian informasi. Serta permasalah spesifik terkait transaksi online berupa jenis-jenis serta jumlah data yang dapat dihimpun dalam pelaksanaan transaksi online menyangkup berbeda negara dalam transaksi maupun layanan online tidak termuat dalam

\section{UUPK;}

Kedua UU No 19 Tahun 2016 mengenai perubahan UU ITE, mempunyai kelemahan tidak mengatur batasan umur atau cakapnya seseorang bagi pelaku usaha dan konsumen dalam melakukan transaksi online memberikan kebebasaan dalam transaksi tanpa melihat pantas/cakapnya pelaku usaha dan konsumen dalam melakukannya. UU ITE juga bertentangan dengan syarat kontrak dalam pasal

1320 KUHPer mengenai cakap seseorang saat mengadakan transaksi pada keadaan nyatanya saat transaksi online mebebaskan siapapun bisa dalam melakukan transaksi online termasuk dalam online marketplace ini sangat mempengaruhi seseorang dalam berbuat tindakan hukum yang menempatkan posisi konsumen dalam posisi yang rugi/lemah. Lalu UU ITE tidak gunakan semestinya untuk ranah transaksi online tetapi saat ini malah sering digunakan untuk keperluan politik;

Ketiga PP No 82 Tahun 2012 (PP PSTE) dibentuk sebagai peraturan pelaksana dari UU ITE juga memiliki kelemah dalam pelaksanaan transaksi online. Yakni pada pasal 49 PP PSTE terdapat mengaharuskan pelaku usaha "menyediakan informasi yang lengkap maupun benar" lalu dalam kontrak harus

"memuat kejelasan informasi" dalam kenyataannya pelanggaran tersebut masih

banyak terjadi, tidak dipenuhinya kewajiban terhadap penyediaan informasi yang lengkap dan benar tersebut dan lalu PP PSTE hanya memberikan sanksi administratif yang terkesan tidak efetif dan cenderung tidak memberikan efek jera terhadap pelaku usaha yang tidak melaksanakannya dan sangat merugikan untuk konsumen dalam hal perlunya informasi.

Kempat UU No 7 Tahun 2014 (UU Perdagangan) juga memiliki kelemah. Hampir sama dengan PP PSTE yakni UU Perdagangan mewajibkan pelaku usaha memberikan informasi identitas dan legalitas pemilik usaha/ produsennya, persyaratan teknis atau klasifikasi barang dan jasa yang ditawarkan, harga dan metode pembayaran, serta maupun pengaturan pengiriman. Pelaku usaha yang tidak melaksanakan memberi informasi tersebut terhadap konsumen akan dikenai sanksi dengan pencabutan izin usaha. Tidak efektif juga layaknya sanksi yang di berikan dalam PP PSTE karena pada kenyataannya sanksi ini sulit dilakukan karena pelaku usaha di Indonesia kebanyakan adalah pengusaha mikro dan informal dengan kurangnya pemahaman terhadap prosedur dan aturan perizinan;

Kelima PP Nomor 80 Tahun 2019 (PP PMSE) yang dibuat guna melengkapi kekurang yang ada dalam di UU Perdagangan juga memiliki kelemah. Yakni pada mekanisme pelaporan ganti rugi dalam PP PMSE tidak selaras dengan UUPK. Pada UUPK menjelaskan dalam melakukan pelaporan permintaan ganti rugi dapat dilaksanakan terutama melalui Badan Penyelesaian Sengketa Konsumen (BPSK) serta juga pengadilan negeri, sedangkan dalam PP PMSE menjelaskan dalam melakukan pelaporan kerugian dilaksanakan melalui Kemendag. Disisi lain pelaporan ganti rugi yang dilaksanakan melalui Kemendag belum memiliki mekanisme untuk memberikan kompensasi kepada konsumen melainkan hanya bisa mencabut izin usaha ini sangat merugikan untuk konsumen; Keenam pada jalur pengaduan juga memiliki masalah yakni konsumen disediakan berbagai jalur pengaduan oleh pemerintah tetapi berberapa lembaga pemerintahan yang terkait tidak terkoordinasi dengan baik antara lembaga- lembaga pemerintahan terkait, serta selain itu konsumen juga harus mengindentifikasi lembaga manakah yangberwenang dalam menangani pengaduan yang konsumen miliki. Hal tersebut merupakan penyebab salah

\section{Marketplace}

Akibat dampak covid-19 masyarakat dibuat untuk mencari solusi dalam mengatasi permasalah yang terjadi dalam situasi pademi virus. Sehingga masyarakat yang sebelumnya tidak pernah berbelanja online kini harus mengandalkan platform belanja online untuk memenuhi kebutuhan mereka. Peningkatan pengguna berbagai platform online marketplace 
seperti Shopee menghadapi kenaikan dari 55,9 juta orang saat tahun 2019 pada saat tahun 2020 penggun mengalami kenaikan sampai 96,5 juta kenaikan persentase $72 \%$. Lalu Tokopedia perlihatkan kenaikan yang sama saat tahun 2019 jumlah pengguna 65,9 juta sedangkan saat tahun 2020 sampai 84,9 juta kenaikan 28\%. Peningkatan disebabkan karena terbukti memberikan solusi dan manfaat kegunaan untuk masyarakat ditengah pademi covid-19.

Menyampingkan sisi baik dari manfaat kegunaan yang membantu masyarakat dari transaksi online marketplace, menurut "Anung Herlianto" sebagai Direktur Eksekutif Penelitian dan Pengaturan Perbankan OJK disisi lain dari peningkatan pengguna tranksaksi online marketplace meningkat pula tingkat kejahatan beriringan yang membayangin masyarakat dengan berbagi modus tindak kejahatan yang dapat sangat merugikan konsumen pada khususnya ditengah kondisi ekonomi serba sulit, peningkatan pertumbuhan transaksi online memang terjadi, tetapi penting dipikirkan adanya terpotensi sengketa yang akan meningkat seiring dengan peningkatan jumlah penggunanya. Ini menunjukan masyarakat sebagai konsumen dalam transaksi online marketplace dibayangin oleh tindak kejahatan baik itu penipuan dengan berbagai modus jadi perlunya kewaspadaan serta kecermatan dan kehati-hatian dalam melakukan transaksi

Dalam membuat regulasi kebijakan perlu melibatkan pihak swasta guna mewujudkan pelaksanaan bisnis onlin yang baik dan bertanggung jawab

Dalam menyusun serta melaksanakan regulasi kebijakan tersebut nantinya, pemerintah dengan pihak swasta perlu berkerjasama dengan memberikan izin kepada pelaku usaha untuk ikut serta menggunakan keahlian teknis di lapangan guna membantu proses membuat regulasi kebijakan atau aturan pemerintah. Dengan melibatkan pihak swasta dapat meningkatkan kepatuhan pihak swasta terhadap UU atau peraturan yang dibuat nantinya.

Perlunya koordinasi yang baik antar institusi pemerintah

Koordinasi yang baik perlu dilakukan oleh institusi pemerintah karena dalam mencegah serta mengatasi permasalah hukum transaksi online maupun mencegah terjadinya peraturan yang kontradiktif menjadi tumpang tindih perlu kerjasama antar institusi pemerintahan tidak bisa diatasi oleh satu institusi pemerintahan saja, perlu koordinasi seperti antara Kemendag, Kemenkominfo, Kemenkeu, BPKN, BPSK, LPKSM, OJK, serta tentunya dari pihak Kepolisian, dan maupun institusi yang lainnya.

Melakukan penyelesaian sengketa konsumen secara online dengan efektif memakai Sistem Informasi Pengaduan Konsumen Nasional (SiPENA)

SiPENA merupakan rancangan gagasan yang dibuat oleh Kemendag bersama BPKN yang direncanakan menjadi mekanisme pengaduan yang mencangkup seluruh pengaduan mengenai masalah yang terjadi dalam bisnis online untuk konsumen, serta tidak akan membingungkan masyarakat (konsumen) lagi karena banyak sistem/ metode pengaduan ada yang dinilai kurang efektif. Serta SiPENA harus terdapat cara-cara non-litigasi dan litigasi dalampenyelesaianperkara yang mudah diakses dan efesien.

Dengan melihat kondisi pademi covid-19 serta masalah hukum yang hadir dalam transaksi online marketplace sepertinya konsumen akan menghadapi berbagai persoalan hukum sedangkan peraturan perlindungan hukum bagi konsumen yang ada sekarang belum mampu melindungi konsumen dalam berbagai hal dalam melakukan transaksi online. Perlunya regulasi kebijakan

perlindungan hukum yang dapat diterapkan, baik berupa undang-undang atau peraturan baru atau kaidah hukum yang disesuaikan dengan kebutuhan dalam menyokong jalannya transaksi online. Perlindungan hukum bagi konsumen online marketplace, yakni harus dengan peran pemerintah langsung untuk melindungi kepentingan konsumen dalam suatu bisnis online.

\section{Implikasi Hukum Penyebaran Covid-19 Terhadap Konsumen Online}

\section{Marketplace}

Akibat dampak covid-19 masyarakat dibuat untuk mencari solusi dalam mengatasi permasalah yang terjadi dalam situasi pademi virus. Sehingga masyarakat yang sebelumnya tidak pernah berbelanja online kini harus mengandalkan platform belanja online untuk memenuhi kebutuhan mereka. Peningkatan pengguna berbagai platform online marketplace seperti Shopee menghadapi kenaikan dari 55,9 juta orang saat tahun 2019 pada saat tahun 2020 penggun mengalami kenaikan sampai 96,5 juta kenaikan persentase 72\%. Lalu Tokopedia 
perlihatkan kenaikan yang sama saat tahun 2019 jumlah pengguna 65,9 juta sedangkan saat tahun 2020 sampai 84,9 juta kenaikan 28\%. Peningkatan disebabkan karena terbukti memberikan solusi dan manfaat kegunaan untuk masyarakat ditengah pademi covid-19.

Menyampingkan sisi baik dari manfaat kegunaan yang membantu masyarakat dari transaksi online marketplace, menurut "Anung Herlianto" sebagai Direktur Eksekutif Penelitian dan Pengaturan Perbankan OJK disisi lain dari peningkatan pengguna tranksaksi online marketplace meningkat pula tingkat kejahatan beriringan yang membayangin masyarakat dengan berbagi modus tindak kejahatan yang dapat sangat merugikan konsumen pada khususnya ditengah kondisi ekonomi serba sulit, peningkatan pertumbuhan transaksi online memang terjadi, tetapi penting dipikirkan adanya terpotensi sengketa yang akan meningkat seiring dengan peningkatan jumlah penggunanya. Ini menunjukan masyarakat sebagai konsumen dalam transaksi online marketplace dibayangin oleh tindak kejahatan baik itu penipuan dengan berbagai modus jadi perlunya kewaspadaan serta kecermatan dan kehati-hatian dalam melakukan transaksi

online karena pelaku tindak kejahatan selalui mengintai korbannya. Selain rawannya tindak kejahatan tersebut juga kendala yang dihadapi pada konsumen saat ingin jalur hukum dengan melakukan gugatan dalam tranksaksi online marketplace, jika melihat syarat-syarat mengenai isi surat gugatan ternyata hanya diatur dalam RVJ (Hukum Acara Perdata), berdasarkan Pasal 8 ayat (3) isi surat gugatan harus memuat identitas para pihak. Identitas penggugat dan tergugat sangat penting, yaitu terdiri nama serta tempat tinggalnya/alamat, pekerjan, jenis kelamin, yang wajib perlu dicantumkan. Menjadi kendala bagi konsumen ketika ingin membuat gugatan terhadap transaksi di dalam online marketplace yakni masalah alamat atau domisi pelaku usaha sulit didapat, karena lapak pelaku usaha di online marketplace tidak mencatumkan alamat jelas pelaku usaha ini menjadi kendala.

Serta Badan Perlindungan Sengketa Konsumen (BPSK) juga menyebutkan, yakni kendala dalam penyelesaian sengketa konsumen belanja online, terutama untuk belanja online lewat platform yakni jika terjadi sengketa, yaitu dalam memenuhi syarat utama yaitu alamat pelaku usaha oleh konsumen untuk penyelesaian sengketa. Alamat sangat penting diperlukan guna memanggil pelaku usaha dalam penyelesaian sengketa. Alamat ini sering tidak dihiraukan oleh konsumen tetapi bisa menyebabkan perkara tidak dapat dilanjutkan. Faktanya demikian kesulitan menemukan alamat pelaku usaha ini membuat penyelesaian sengketa yang muncul dari transaksi online marketplace menjadi sulit dilaksanakan. Ketika konsumen bertanya ke pihak online marketplace, pihak operator cenderung tidak merespon dan tidak memberitahu ketika konsumen mengalami kasus serta jika pun pihak marketplace memberitau sulit dipercaya dan belum tentu alamat tersebut benar karena pada dasarnya pihak marketplace tidak pernah melakukan verifikasi kepada pengguna yang ingin membuka lapak dagangan. Sulitnya mencari identitas pelaku usaha perseorangan merupakan satu persoalan yang cukup krusial ketika melakukan penyelesaian sengketa transaksi online marketplace. Berdasarkan Pasal $94 \mathrm{Rvj}$ (hukum acara perdata) menjelaskan bahwa jika Pasal 8 Rvj tidak dipenuhi maka bisa mengakibatkan gugatan tersebut batal. Jadi maka dapat diartikan bahwa yang dimaksud gugatan hak disini harus

memenuhi syarat dari hukum acara perdata jika tidak gugatan tersebut bisa disebut tidak mengandung sengketa karena kurangnya syarat yang harus dipenuhi dalam surat gugatan.

Serta dari pihak online marketplace pun kurang responsif kepada penggunanya aplikasinya (konsumen), karena ketika konsumen melakukan pengaduan saat terjadi permasalahan dalam transaksi ketika konsumen menanyakan alamat pelaku usaha guna dapat melakukan gugatan, pihak operator marketplace sendiri sering lamban bahkan tidak menanggapi pengaduan yang dilakukan konsumen. Jadi kurang tegasnya pihak online marketplace dalam menindak pelaku usaha yang merugikan konsumen, serta jika pun pihak marketplace melakukan penindakan hanya sebatas teguran serta pemblokiran lapak pelaku usaha saja jadi kurang efektif, dan serta tanpa ada pelaksanaan ganti rugi kepada konsumen.

\section{Simpulan}

Bahwa melihat peraturan perlindungan hukum terkait tranksaksi online marketplace sudah diatur didalam UUPK, UU ITE, UU Perdagangan, PP PSTE, dan PP PMSE tetapi belum efektif, dirasa tumpang tindih serta tidak kosisten isi antara peraturan sehingga perlu diselaraskan antar undangundang satu dengan undang-undang lainnya. Perlunya regulasi kebijakan perlindungan hukum baru maupun merevisi peraturan sudah 
ada agar yang dapat diterapkan, serta disesuaikan dengan kebutuhan saat ini dalam melindungi konsumen, dan menyokong jalannya transaksi online marketplace saat ini dan kedepan. Maka referensi yang diberikan semoga dapat digunakan oleh pemerintah untuk dijadikan bahan pertimbangan dalam rangka memperbaiki regulasi kebijakan perlindungan hukum terkait transaksi online.

Implikasi hukum penyebaran covid-19 terhadap konsumen online marketplace yakni, meningkatnya pengguna online marketplace disituasi pademi covid-19 secara bersamaan juga peningkatan tindak kejahatan juga meningkat yang membuat masyarakat sebagai konsumen kawatir akan menjadi korban. Serta dari pihak online marketplace pun kurang responsif serta lamban dalam

menanggapi pengaduan kepada konsumen, saat terjadi permasalahan dalam transaksi. Kurang tegasnya pihak online marketplace dalam menindak pelaku usaha yang merugikan konsumen sehingga kinerjanya perlu dibenahi. Serta perlu aturan hukum yang sesuai agar mampu mengatasi masalah hukum yang terjadi, dan memastikan kepatuhan pihak online marketplace dalam membantu terpenuhinya hak konsumen.

\section{DAFTAR PUSTAKA}

Atmadja, I. D. G., Budiartha, I. N. P. (2018). Teori-Teori Hukum. Malang: Setara Press.

Barkatullah, A. H. (2003). Tinjauan Hukum Bisnis E-Commerce. Tesis, Program Pascasarjana Universitas Gadjah Mada. Yogyakarta.

Barkahtullah, A. H. (2009). Perlindungan Hukum Bagi Konsumen dalam Transaksi E-Commerce Lintas Negara di Indonesia. Yogyakarta: FH UII Press.

Nurmadjito. (2000). Kesiapan Perangkat Peraturan Perundang-Undangan dalam Menghadapi Era Globalisasi. Jakarta: Mandar Maju.

Sidabalok, J. (2014). Hukum Perlindungan Konsumen di Indonesia. Bandung: Citra Aditya Bakti. 